\title{
Corporate sustainability performance assessment: an analytical hierarchy process approach
}

\author{
Praveen Goyal* \\ Department of Management, \\ Birla Institute of Technology \& Science, \\ Pilani, Rajasthan, India \\ Email: praveeng23@gmail.com \\ *Corresponding author
}

\section{Zillur Rahman}

Department of Management Studies,

Indian Institute of Technology Roorkee,

Roorkee, India

Email: yusuffdm@iitr.ernet.in

\begin{abstract}
The objective of this study is to develop a model to measure the corporate sustainability performance of the oil and gas industry using an analytical hierarchy process. A top-down approach was used for selecting sustainability indicators based on three dimensions: social, environmental and economic. The model was applied to the case company to assess sustainability performance and for validation purposes. The assessment discloses a little improvement in corporate sustainability performance of the company. Therefore, the model may help analyse corporate sustainability performance in view of a competitive advantage in the long run. This model will also help stakeholders assess the sustainability performances of particular companies and their relative performances with competitors. This model may help develop a set of standards for a particular sector so companies may improve their sustainability performance.
\end{abstract}

Keywords: analytical hierarchy process; corporate sustainability assessment; India; oil and gas.

Reference to this paper should be made as follows: Goyal, P. and Rahman, Z . (2014) 'Corporate sustainability performance assessment: an analytical hierarchy process approach', Int. J. Intercultural Information Management, Vol. 4, No. 1, pp.1-14.

Biographical notes: Praveen Goyal is an Assistant Professor in the Department of Management, Birla Institute of Technology \& Science, Pilani, Rajasthan. He has completed his Doctoral in the area of Corporate Sustainability from IIT Roorkee. He has authored several articles related to corporate sustainability and CSR. His areas of interest are service marketing, strategic management and CSR.

Zillur Rahman has received his MBA and $\mathrm{PhD}$ in Business Administration. Currently, he is working as an Associate Professor at the Department of Management Studies, Indian Institute of Technology, Roorkee. His research interests are business strategy, international marketing and corporate 
sustainability. He has several publications in reputed national and international journals. He was the recipient of the Emerald Literati Club Highly Commended Award in 2004 and the Emerald/AIMA Research Fund Award in 2009.

This paper is a revised and expanded version of a paper entitled 'Corporate sustainability performance assessment: an analytical hierarchy process approach' presented at the 'International Conference on Management and Business Innovation', MNIT Jaipur, India, 18-19 May 2013.

\section{Introduction}

In the last three decades, corporate environmentalism, Corporate Social Responsibility (CSR) and corporate sustainability have become an important part of the strategy for business organisations. Changing climate conditions, global warming and awareness among different stakeholders have made it imperative to include sustainable development in the business process. Efforts by both government and non-government organisations around the world are one of the main reasons behind this changing mindset. It is necessary for companies, especially from the manufacturing sector, to make a substantial contribution in sustainability development. The availability and supply of energy plays an important role in the development of any economy. Oil and gas is an integral part of long-term energy requirements. At the same time, the blind exploration and consumption of this commodity has a hazardous effect on both society and the environment. Therefore, it is imperative for oil and gas companies to pursue sustainable development. There are many companies involved with activities for the welfare of society and environmental protection, showing sincere efforts towards sustainable development. Therefore, how can company efforts towards sustainable development be measured? These efforts can be measured by focusing on the triple bottom line of sustainable development. This triple bottom line includes environmental, social and economic performances. Companies are involved in various efforts like community development, technology upgradation, health and the safety of employees and the community to contribute to sustainable development.

Initially, companies were using financial disclosures to measure the business performance. In the current scenario, due to an increasing demand from various stakeholders, companies are publishing corporate sustainability reports. The publication of sustainability reports is a new trend in corporate disclosures to highlight their efforts towards sustainable development (GRI, 2002). In their reports, companies show their sustainability performance based on a large number of indicators (Azapagic and Perdan, 2000). The main goal of these indicators is to measure the efforts taken towards sustainable development (Guy and Kibert, 1998).

In this backdrop, a need has been identified to develop a comprehensive industryspecific corporate sustainability performance measurement framework that can be used for measuring the corporate sustainability performance of any specific firm. A large number of indicators have been suggested by various agencies to assess improvements at manufacturing sites (Sikdar, 2003). World Business Council for Sustainable Development (WBCSD), Global Reporting Initiatives (GRI), ISO 14000 and EMAS standards are the key institutions behind the growth of sustainability reporting. Several studies on mineral 
and mining (Azapagic, 2004), steel industry (Singh et al., 2007), construction (Ugwu and Haupt, 2007) and telecommunication (Kang et al., 2010) developed specific performance assessment methods by using various sustainability indicators. Although in recent years, various indexes have been developed for measuring sustainability at the national level or for cross-country comparisons, but the issue of developing an index at the company level is not properly addressed in the literature.

The present study developed a composite sustainability index for measuring corporate sustainability performance at the firm level. To achieve the objective, the most widely accepted structure of sustainable development, including the three basic dimensions of corporate sustainability, has been used (Krajnc and Glavic, 2005). The index has been developed by using a multi-criteria decision-making model method Analytical Hierarchy Process (AHP) (Saaty, 1980). The normalised value of various indicators was used to assess the performance.

\section{Literature review}

Sustainability assessment has become one of the most important issues in the current dynamic business environment (Goyal et al., 2013). Availability of corporate sustainability reports facilitates the assessment of corporate sustainability performance. These reports show the efforts of companies based on certain indicators of sustainability. Various studies have used the data given in these reports for measuring the sustainability performance of the respective companies (Klassen and McLaughlin, 1996; Jacobs et al., 2010). In the earlier studies, these reports have been used in two ways. The first is by applying a content analysis on corporate disclosures. This method, however, suffers from certain limitations. The most important limitation is the exaggeration of efforts may lead to the wrong assessment. The second limitation is that it does not categorise indicators into different categories based on their importance.

The second method used in the studies is the weighting method, which is used for making assessments. Weighting methods provide different weights to the categories and indicators as per their priorities. The majority of the studies in this category applied AHP to assess the weights of the indicators (Singh et al., 2007; Krajnc and Glavic, 2005; Kang et al., 2010). The AHP provides weights based on expert decisions. Since the majority of the studies are based on developed countries, the literature shows a lacuna of these types of studies in the Indian context.

\section{Research methodology}

The present paper is mainly aimed at designing a composite sustainability index using different sustainability indicators. In the initial section, this study identified important indicators for the oil and gas industry with the help of a literature review and experts. In later sections, using the AHP methodology, weights have been given to all the shortlisted indicators. 


\subsection{Identification of sustainability indicators}

For the present study, sustainability indicators have been selected based on theory, literature and the discretion of several experts in the field of sustainable development and corporate sustainability. The literature provided a huge list of indicators including indicators that overlapped each other. After the finalising the initial list of indicators from the literature, a brainstorming session was conducted. After the discussion, approximately 29 indicators were finalised. Then an expert survey was carried out to finalise the indicators to develop the final model. These experts were from both the oil and gas industry and academia. The survey involved ten business managers and ten experts from the academia. These experts are involved with corporate sustainability adoption and implementation in the companies, or they are experts in this field of research. All the experts provided their response to a five-point Likert scale (5 indicates the highest importance and 1 indicates the lowest importance). Indicators with a mean value of more than 3 were selected for inclusion in the model. Finally, after the brainstorming session and interviews, 21 indicators were shortlisted for the oil and gas sector. The list of shortlisted indicators is given in Table 1.

Table 1 List of shortlisted sustainability key indicators

\begin{tabular}{clll}
\hline S. No. & \multicolumn{1}{c}{ Economic } & \multicolumn{1}{c}{ Social } & \multicolumn{1}{c}{ Environment } \\
\hline 1 & Net profit & Social expenditure & Raw material consumption \\
2 & Retained EVA & HSE expenses & Material recycling \\
3 & Contribution to tax & Attrition rate & Renewable energy \\
4 & Payment to employee & Benefits to employee & Water recycling \\
5 & & No. of reported injuries & $\mathrm{NO}_{\mathrm{x}}$ \\
6 & & No. of employees & Hazardous waste \\
7 & & & Energy saving \\
8 & & & Effluent discharge \\
9 & & & Reduction in GHG emission \\
10 & & & SO $_{\mathrm{x}}$ \\
11 & & & Environment investment \\
\hline
\end{tabular}

\section{AHP methodology}

The present study designed a model for assessing the corporate sustainability performance for oil and gas companies with respect to time. In this paper, the AHP technique was used to serve the purpose of the study.

The AHP is a famous and well-adopted multi-criterion decision-making technique developed by T.L. Saaty. Since its introduction, this method has gained popularity among researchers for solving complex multifaceted problems (Partovi, 1994). This technique has been used in different areas like supplier selection, industry selection, stakeholder prioritisation and sustainable development. This technique can incorporate both qualitative and quantitative variables simultaneously, which is an important feature. It is also highly suitable for the selection and weighted aggregation of different indicators into 
a single compound index (Singh et al., 2007). The AHP contains various steps to convert a complex problem into a hierarchical structure (Saaty, 1994). In this hierarchical model, the top stands for the overall goal of decision-making. In the present case, the goal is to assess corporate sustainability performance. This method decomposes a complex problem into a smaller problem set and then makes pairwise comparisons with the help of experts on a 1-9 scale (Saaty, 1980).

The present model follows the same approach for developing an index of the basic structure, which is given in Figure 1. The identified indicators were applied to the development of a composite sustainability assessment index for the oil and gas industry. The next stage in the development of the model was to weight determination of the indicators. Weights were obtained from different experts in the field of sustainable development. The data were collected by a survey that yielded 30 responses. Comparisons were made by providing a question asking which indicator $i$ or $j$ is more important in the measurement of corporate sustainability performance for the oil and gas industry. Responses were given on a scale from 1 to 9 (Table 2).

Table 2 Nine-point intensity scale for analytical hierarchy process

\begin{tabular}{cl}
\hline Factor of preference $(p)$ & \multicolumn{1}{c}{ Definition of importance } \\
\hline 1 & Equally important \\
3 & Moderately important \\
5 & Strong or essential important \\
7 & Very strong or demonstrated important \\
9 & Extremely important \\
$2,4,6,8$ & Intermediate values \\
\hline
\end{tabular}

Figure 1 Basic structure of proposed model

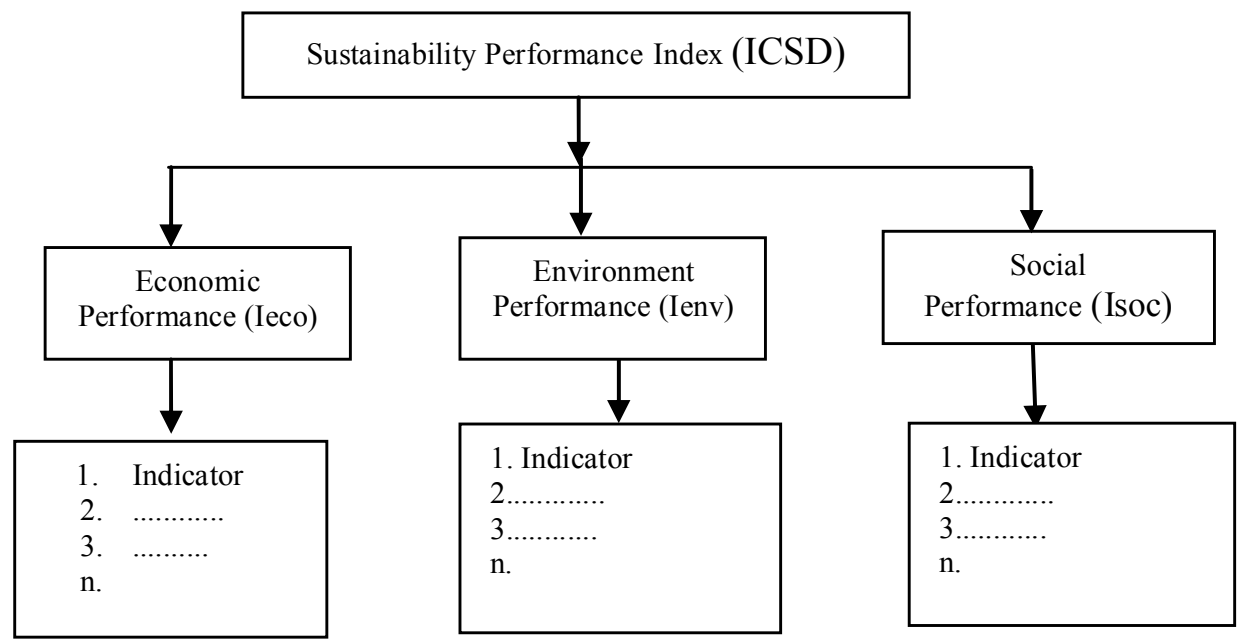


On this scale, 1 means that both indicators possess an equal importance in the context of the goal of the study and 9 means that one indicator is extremely important to another one. The basic assumption for adopting this scale is the respondents are sensitive enough to distinguish values with their relative meanings. This pairwise comparison resulted in the $N \times N$ positive reciprocal matrix $A$. In this matrix diagonal $a_{i i}=1$. If indicator $i$ is ' $p$ times' important in comparison to indicator $j$, a reciprocal value will be there. This process was repeated for all the other indicators in the same matrix by developing all possible independent pairs of different indicators. The next step was to calculate the normalised value of each column by dividing the respective column total and calculating the average value across the rows. The results gave a normalised weight vector for the shortlisted sustainability indicators. Another benefit of the AHP method is the ability to check the consistency of pairwise comparison by calculating the Consistency Ratio (CR). The upper ceiling of the CR is 0.1 . If the calculated consistency ratio value exceeds 0.1 , then decision makers should reassess the comparison matrix. The calculation of CR ensures the consistency of the responses provided by the respondents. Final $I_{C S D}$ is calculated by summing the values of the sub-indices. For this purpose, the $W_{i j}$ (weight) calculated by the AHP method of every indicator for every group is multiplied by the value of the respective indicator in a particular year. These values are added as per their respective signs. The mathematically composite sustainability index can be presented as

$$
\begin{aligned}
& I_{S, i j t}=\sum_{j t i}^{n} W_{j i .} \cdot I_{N, j t i}^{+}+\sum_{j t i}^{n} W_{i j} \cdot I_{j t i}^{-} \\
& \sum_{i j}^{n} W_{j i j i .}=1, W_{i} j \geq 0 \\
& I_{C S D, t}=\sum_{i t}^{n} W_{i .} \cdot I_{S, i t} \\
& I_{S, i j t}-\text { Value of particular criteria in the year } t \\
& W_{i} j-\text { Weight of every indicator } \\
& I_{j} t i^{-}-\text {Value of the indicator in the yeart with positive influence on sustainability } \\
& I_{N, j t i}^{+}-\text {Value of the indicator in the year } t \text { with negative influence on sustainability } \\
& I_{C S D, t}-\text { Final value of composite sustainability performance index }
\end{aligned}
$$

\section{Case study}

Further, the validity and the effectiveness of the proposed model have been investigated in a case study. The Indian oil and gas sector serves $45 \%$ of the country's energy demand (KPMG, 2009). Data for validating the model have been collected from the corporate sustainability reports of Reliance Industries. Reliance Industries is one of the leading players in this sector and among the Global Fortune 500 companies. The case company has published its corporate sustainability report regularly since the financial year 2004-2005. Reliance Industries Limited is the only Indian company included in the world's top 100 sustainable companies by Corporate Knights (Reliance, 2012). The proposed model has been implemented for the case company from the financial year 2009-2010 to 2011-2012 (Reliance, 2012; Reliance, 2011; Reliance, 2010). The normalised value of indicators has been provided in Tables 3-5. 
Figure 2 Composite index development process

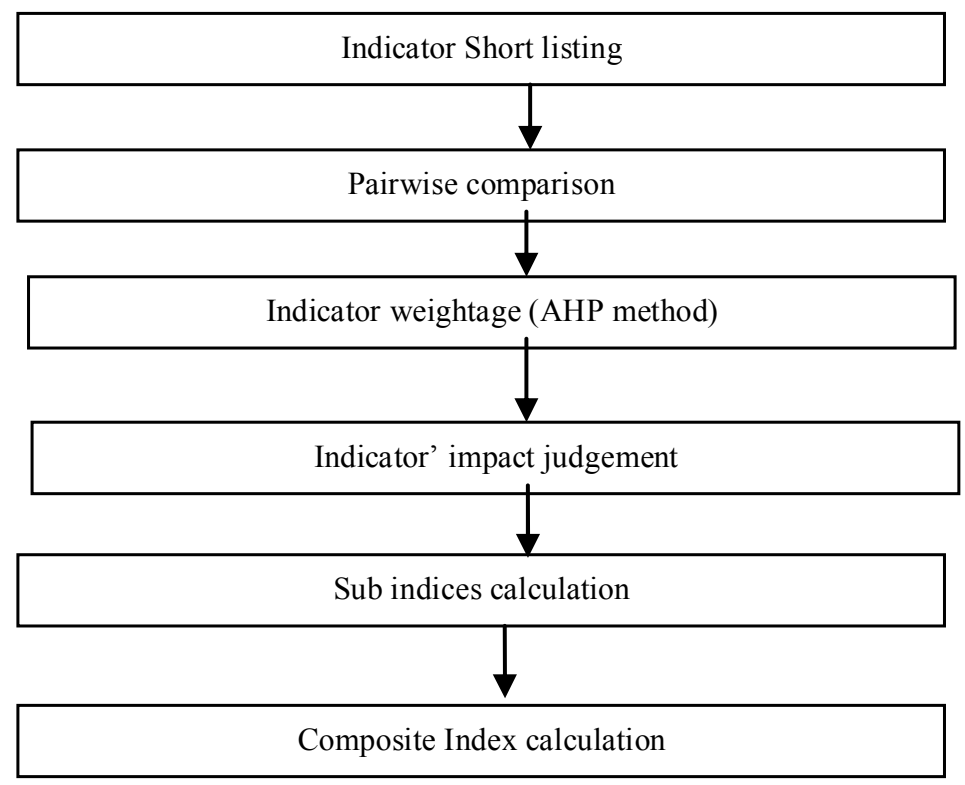

\section{Economic dimension}

Economic indicators related to the economic performance of the firm for the different stakeholders were used (Azapagic, 2004). For measuring economic performance, four indicators have been shortlisted by the experts. All these indicators have a positive impact on the firm's economic performance.

Table 3 Economic indicators

\begin{tabular}{lccccc}
\hline & Unit & 2009-2010 & 2010-2011 & 2011-2012 & Average \\
\hline Net profit & (INR billion) & 162.36 & 202.86 & 200.40 & 188.54 \\
Retained EVA & (INR million) & 255,013 & 317,575 & 290,528 & 287705.3 \\
Contribution to tax & (INR billion) & 179.72 & 287.2 & 281.97 & 249.63 \\
Employee cost & (INR million) & 23,504 & 26,242 & 28,616 & 26120.67 \\
\hline
\end{tabular}

\section{Environmental dimension}

The impact of the firm's process on the natural environment is an important issue for the sustainable development of the world (Jiménez and Lorente, 2001). The indicators for measuring the environmental performance include various environmental issues (Azapagic, 2004). In the current competitive scenario, disclosure of a firm's efforts towards better environmental performance in terms of material use, energy consumption and operational efficiency is important (IChemE, 2004). Table 4 shows the numerical values of the environmental indicators. 
Table 4 Environment indicators

\begin{tabular}{lccccc}
\hline & Unit & $2009-2010$ & $2010-2011$ & $2011-2012$ & Average \\
\hline Raw material consumption & '000 ton & $68,089.79$ & $74,086.83$ & $76,159.78$ & 72778.8 \\
Material recycling & '000 ton & 74.63 & 73.43 & 64.88 & 70.98 \\
Renewable energy & '000 GJ & 522.58 & 463.48 & 483.18 & 489.75 \\
Water recycling & '000 Cu. M & 47818.47 & 60704.59 & 65158.56 & 57893.87 \\
$\mathrm{NO}_{\mathrm{x}}$ & '000 ton & 23.26 & 29.42 & 28.93 & 27.20 \\
Hazardous waste & '000 ton & 56.16 & 51.34 & 58.74 & 55.41 \\
Energy saving & '000 GJ & 5858.14 & 2431.33 & 2227.76 & 85.42 \\
Effluent discharge & '000 Cu. M & 21.324 .14 & $22,390.69$ & $21,977.98$ & 21897.6 \\
Reduction in GHG emission & '000 ton & $1,220.25$ & 395.46 & 435.27 & 683.66 \\
SO $_{x}$ & '000 ton & 12.82 & 11.39 & 10.14 & 11.45 \\
Environment investment & INR million & 1.71 & 7.64 & 21.50 & 37.48 \\
\hline
\end{tabular}

\section{Social dimension}

Defining social indicators is a difficult task for firms, since these issues attract the attention of the majority of stakeholders in a business organisation (Azapagic, 2004). GRI provided an exhaustive list of indicators, but that list is not applicable across industries and this is the reason for an absence of common agreement on the list of social indicators (GRI, 2002). In the current case, six indicators were shortlisted for measuring the social performance of the case company.

Table 5 Social indicators

\begin{tabular}{lccccc}
\hline & Unit & 2009-2010 & 2010-2011 & 2011-2012 & Average \\
\hline Social expenditure & (INR million) & 1784.89 & 2013.41 & 2512.68 & 2103.66 \\
HSE expenses & (INR million) & 845.18 & 968.94 & 966.46 & 926.86 \\
Attrition rate & $(\%)$ & 8.45 & 7.91 & 7.57 & 7.976667 \\
Benefits to employee & (INR million) & 3722.30 & 4449.60 & 4284.00 & 4151.967 \\
No. of reported injuries & (Nos.) & 51 & 64 & 73 & 62.66667 \\
No. of employees & (Nos.) & 23,365 & 22,661 & 23,166 & 23,064 \\
\hline
\end{tabular}

After selecting the indicators for the development of a composite corporate sustainability performance index, the next step was to perform a pairwise comparative analysis with the goal of corporate sustainability performance. The pairwise comparison was performed for all the selected indicators. The measurement units of these indicators are different. Therefore, the normalised value has been calculated to make them unitless. Normalisation was performed by dividing the value of the indicator by the average value of all the years included in the study.

\section{Results}

Corporate sustainability performance for the case company was computed for three years using 21 indicators. These included four indicators of economic performance, 11 indicators of environmental performance and six for the social performance measurement 
of the case company. First, sub-indices were computed followed by the calculation of the composite sustainability index. Equal weight was provided for the three dimensions of corporate sustainability.

Table 6 Pairwise comparison matrix of economic indicators

\begin{tabular}{lccccc}
\hline & Net profit & Retained EVA & Contribution to tax & Payment to employee & Weights \\
\hline Net profit & 1 & 1 & 3 & 1 & \\
Retained EVA & 1 & 1 & 2 & 2 & 2 \\
Contribution to tax & 1 & 0.5 & 1 & 1 & \\
$\begin{array}{l}\text { Payment to } \\
\text { employee }\end{array}$ & 1 & 0.5 & 0.5 & 6.00 & \\
$\sum$ & 3.33 & 3.00 & 6.50 & 0.167 & 0.315 \\
Net profit & 0.3 & 0.333 & 0.462 & 0.333 & 0.319 \\
Retained EVA & 0.3 & 0.333 & 0.307 & 0.333 & 0.188 \\
Contribution to tax & 0.1 & 0.167 & 0.154 & 0.167 & 0.178 \\
Payment to & 0.3 & 0.167 & 0.0769 & & \\
employee & & & &
\end{tabular}

The composite value of the sustainability index along with the individual social, economic and environmental indexes for the study period was calculated. The results have been provided in Tables 9-12. The graphical presentation of the results is given in Figure 3 . The overall result of the study does not show any remarkable growth in the sustainability performance of the case company. There is a downfall in the company's corporate environmental performance from 2009-2010 to 2010-2011. However, due to sincere efforts taken by the management, the company regained its environmental performance. Economic performance shows a growing trend in the study period. The developed index provides a trend for the corporate sustainability performance. This index will provide guidelines for the scope of improvement to perform better in the field of corporate sustainability to achieve a competitive advantage. This model will also be helpful for setting benchmarks in particular industries.

Figure 3 Graphical representation of result (see online version for colours)

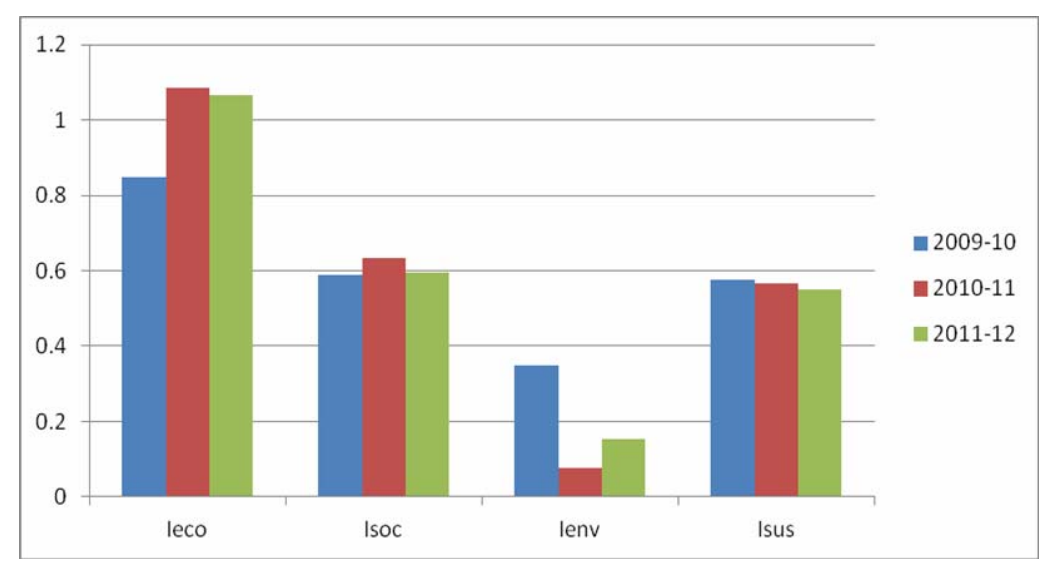


Table 7 Pairwise comparison matrix of social indicators

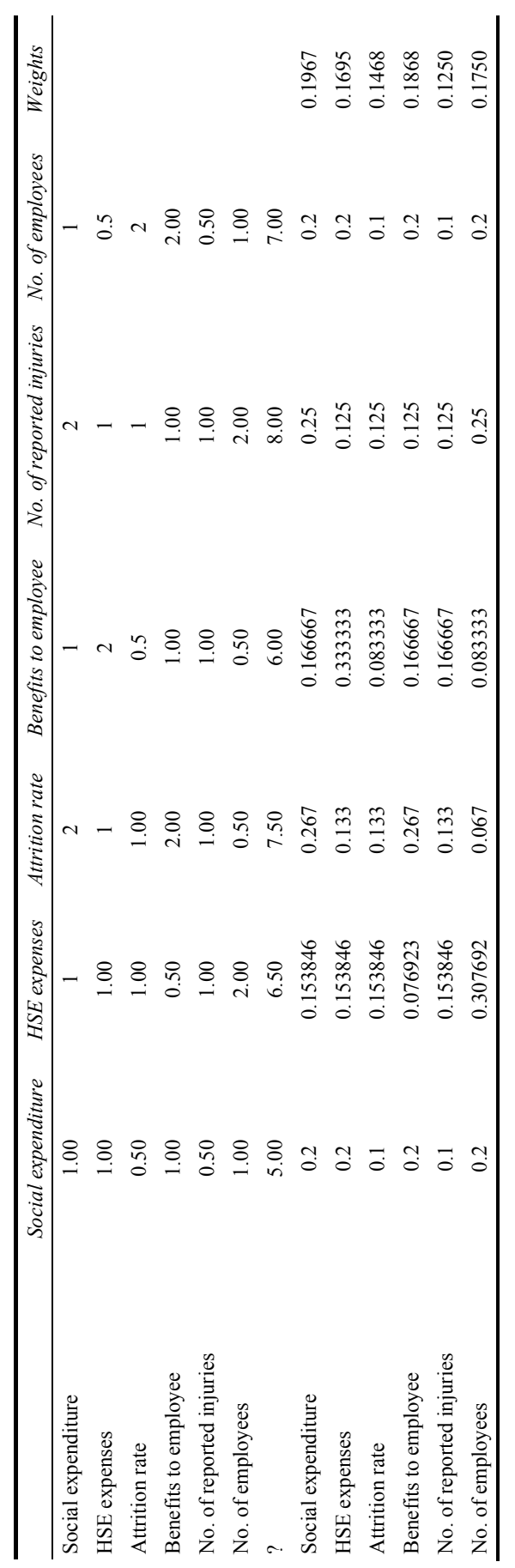


Table 8 Pairwise comparison of environmental indicator

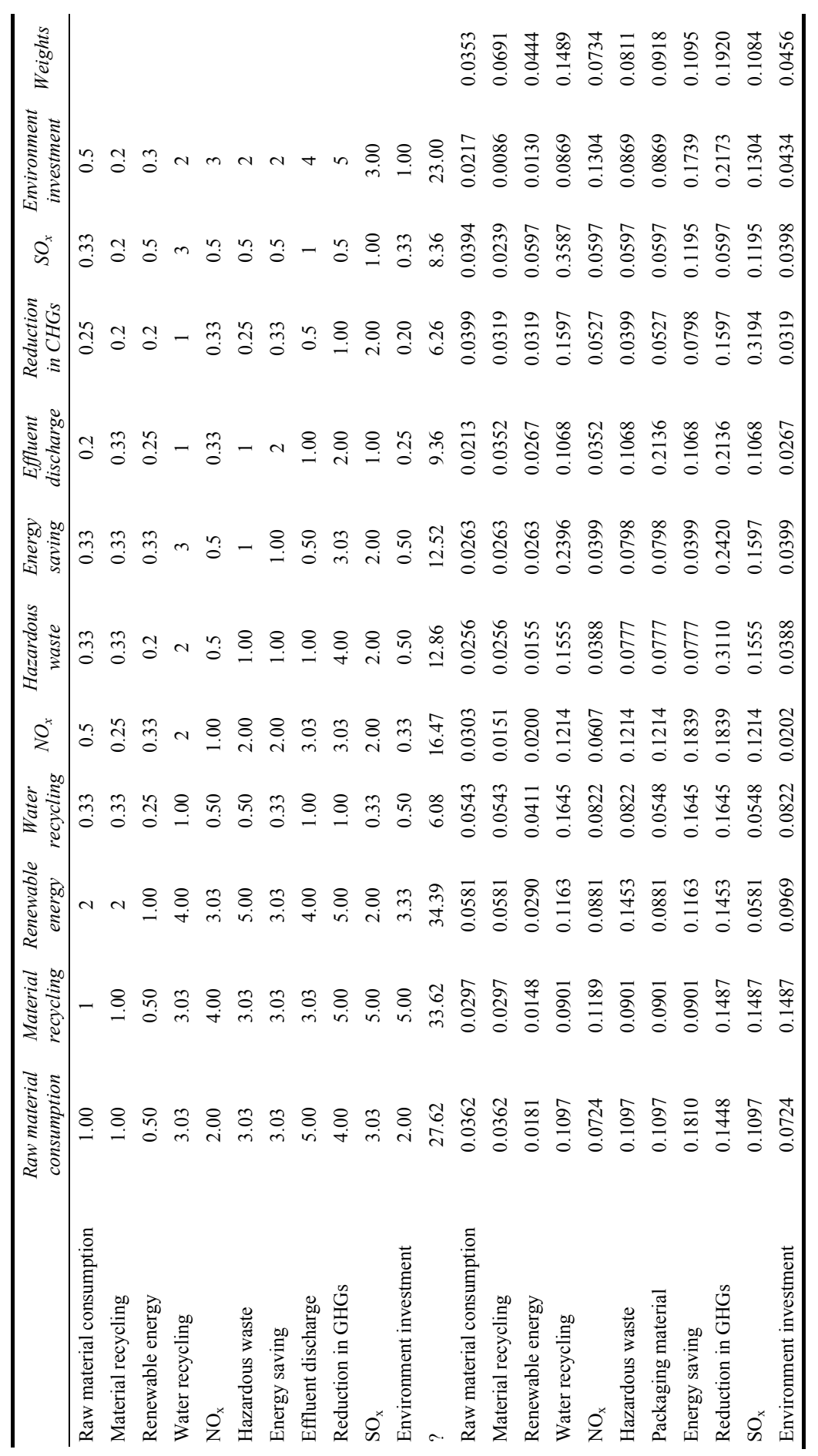


Table 9 Normalised value of economic indicators

\begin{tabular}{lccccc}
\hline & Sign & $2009-2010$ & $2010-2011$ & $2011-2012$ & Weights \\
\hline Net profit & $(+)$ & 0.861144 & 1.075952 & 1.062904 & 0.315 \\
Retained EVA & $(+)$ & 0.886369 & 1.10382 & 1.009811 & 0.319 \\
Contribution to tax & $(+)$ & 0.719946 & 1.150503 & 1.129552 & 0.188 \\
Employee cost & $(+)$ & 0.899824 & 1.004645 & 1.095531 & 0.178 \\
\hline
\end{tabular}

Table 10 Normalised value of environment indicators

\begin{tabular}{lccccc}
\hline & Sign & $2009-2010$ & $2010-2011$ & $2011-2012$ & Weights \\
\hline Raw material consumption & $(-)$ & 0.935572 & 1.017973 & 1.046456 & 0.031054 \\
Material recycling & $(+)$ & 1.051423 & 1.034517 & 0.91406 & 0.066374 \\
Renewable energy & $(+)$ & 1.067041 & 0.946367 & 0.986592 & 0.051054 \\
Water recycling & $(+)$ & 0.825968 & 1.048549 & 1.125483 & 0.149122 \\
$\mathrm{NO}_{\mathrm{x}}$ & $(-)$ & 0.855042 & 1.081485 & 1.063473 & 0.073491 \\
Hazardous waste & $(-)$ & 1.013475 & 0.926492 & 1.060034 & 0.081735 \\
Energy saving & $(+)$ & 1.101807 & 1.141843 & 0.756351 & 0.091832 \\
Effluent discharge & $(-)$ & 0.973812 & 1.022518 & 1.003671 & 0.109573 \\
Reduction in GHG emissions & $(+)$ & 1.784878 & 0.578445 & 0.636676 & 0.192117 \\
SO $_{\mathrm{x}}$ & $(-)$ & 1.119651 & 0.99476 & 0.88559 & 0.107611 \\
Environment investment & $(+)$ & 0.779813 & 1.076212 & 1.143975 & 0.046036 \\
\hline
\end{tabular}

Table 11 Normalised value of social indicators

\begin{tabular}{lccccc}
\hline & Sign & $2009-2010$ & $2010-2011$ & $2011-2012$ & Weights \\
\hline Social expenditure & $(-)$ & 0.848469 & 0.957099 & 1.194433 & 0.196673 \\
HSE expenses & $(+)$ & 0.911875 & 1.045401 & 1.042725 & 0.16949 \\
Attrition rate & $(+)$ & 1.05934 & 0.991642 & 0.949018 & 0.146871 \\
Benefits to employee & $(+)$ & 0.896515 & 1.071685 & 1.0318 & 0.186828 \\
No. of reported injuries & $(+)$ & 0.81383 & 1.021277 & 1.164894 & 0.125046 \\
No. of employees & $(+)$ & 1.013051 & 0.982527 & 1.004422 & 0.175092 \\
\hline
\end{tabular}

Table 12 Sustainability index and sub-index of economic, environmental and social indicators

\begin{tabular}{cccc}
\hline & $2009-2010$ & $2010-2011$ & $2011-2012$ \\
\hline$I_{\text {eco }}$ & 0.649 & 1.024 & 1.320 \\
$I_{\text {env }}$ & 0.102 & 0.191 & 0.586 \\
$I_{\text {soc }}$ & 0.684 & 0.692 & 1.145 \\
$I_{\text {Sus }}$ & 0.473 & 0.629 & 1.006 \\
\hline
\end{tabular}




\section{Conclusion}

The oil and gas sector is one of the most important sectors of any economy because it fulfils the energy requirements of the country. These companies are looking for new prospects that will contribute to the sustainable development of the world. The adoption of sustainability practices and motivation for improving corporate sustainability performance have become critical issues among corporate stakeholders.

The main objective of the present study is to provide a model that gives a comprehensive sustainability assessment of the oil and gas sector. This paper is structured according to the process of generalised development models that are applicable to specific cases. The most important outcome of this study is that it can provide the scope of improvement to make a better contribution towards sustainable development.

This study also contains some limitations. These limitations are related to the methodology used. The collection of data from experts may bias the results leading to different results. Therefore, the further reassessment of pairwise comparisons may give better results or further verifications could be done with the help of a different group of experts.

\section{References}

Azapagic, A. (2004) 'Developing a framework for sustainable development indicators for the mining and minerals industry', Journal of Cleaner Production, Vol. 12, No. 6, pp.639-662.

Azapagic, A. and Perdan, S. (2000) 'Indicators of sustainable development for industry: a general framework', Process Safety and Environmental Protection, Vol. 78, No. 4, pp.243-261.

Goyal, P., Rahman, Z. and Kazmi, A.A. (2013) 'Corporate sustainability performance and firm performance research literature review and future research agenda', Management Decision, Vol. 51, No. 2, pp.361-379.

GRI (2002) Sustainability reporting guidelines 2002, Global Reporting Initiative. Available online at: www.unep.fr/scp/gri/pdf/gri_2002_guidelines.pdf

Guy, G.B. and Kibert, C.J. (1998) 'Developing indicators of sustainability: US experience', Building Research \& Information, Vol. 26, No. 1, pp.39-45.

IChemE (2004) Sustainable development progress metrics recommended for use in the process industries. Available online at: http://www.icheme.org/sustainability/metrics.pdf (accessed on 13 May 2012).

Jacobs, B.W., Singhal, V.R. and Subramanian, R. (2010) 'An empirical investigation of environmental performance and the market value of the firm', Journal of Operations Management, Vol. 28, No. 5, pp.430-441.

Jiménez, J.B. and Lorente, J.J.C. (2001) 'Environmental performance as an operations objective', International Journal of Operations and Production Management, Vol. 21, No. 12, pp.1553-1572.

Kang, Y., Ryu, M. and Kim, S. (2010) 'Exploring sustainability management for telecommunications services: a case study of two Korean companies', Journal of World Business, Vol. 45, No. 4, pp.415-421

Klassen, R.D. and McLaughlin, C.P. (1996) 'The impact of environmental management on firm performance', Management Science, Vol. 42, No. 8, pp.1199-1214.

KPMG (2009) The oil and gas sector overview in India 2009. Available online at: http://www. kpmg.de/14725.htm (accessed on 12 February 2012). 
Krajnc, D. and Glavic, P. (2005) 'A model for integrated assessment of sustainable development', Resources, Conservation and Recycling, Vol. 43, No. 2, pp.189-208.

Partovi, F.Y. (1994) 'Determining what to benchmark: an analytic hierarchy process approach', International Journal Operation Production Manufacturing, Vol. 14, No. 6, pp.25-39.

Reliance (2010) Think sustainability, think transformation, think Reliance. Available online at: http://www.ril.com/downloads/pdf/RIL_SR2009_10.pdf (accessed on 13 May 2012).

Reliance (2011) New businesses. New technologies. New partnerships. Available online at: http://www.ril.com/downloads/pdf/ril_sr2010_11.pdf (accessed on 13 May 2012).

Reliance (2012) Partnering India's new future. Sustainably. Available online at: http://www. ril.com/downloads/pdf/ril_sr2011_12.pdf(accessed on 13 May 2012).

Saaty, T.L. (1980) The Analytic Hierarchy Process, McGraw-Hill, New York.

Saaty, T.L. (1994) 'How to make a decision: the analytic hierarchy process', Interfaces, Vol. 24, No. 6, pp.19-43.

Sikdar, S.K. (2003) 'Sustainable development and sustainability metrics', AIChE Journal, Vol. 49, No. 6, pp.1928-1932.

Singh, R.K., Murty, H.R, Gupta, S.K. and Dikshit, A.K. (2007) 'Development of composite sustainability performance index for steel industry', Ecological Indicators, Vol. 7, No. 3, pp.565-588.

Ugwu, O.O. and Haupt, T.C. (2007) 'Key performance indicators and assessment methods for infrastructure sustainability: a South African construction industry perspective', Building and Environment, Vol. 42, No. 2, pp.665-680. 